\title{
Rheological properties and microstructure of Cheddar cheese made with different fat contents
}

\author{
N. R. Rogers, ${ }^{*}$ D. J. McMahon,† C. R. Daubert, ${ }^{*}$ T. K. Berry, ${ }^{*}$ and E. A. Foegeding ${ }^{* 1}$ \\ ${ }^{*}$ Department of Food, Bioprocessing and Nutrition Sciences, North Carolina State University, Raleigh 27695 \\ †Western Dairy Center, Department of Nutrition, Dietetics and Food Sciences, Utah State University, Logan 84322
}

\begin{abstract}
Reduced- and low-fat cheeses are desired based on composition but often fall short on overall quality. One of the major problems with fat reduction in cheese is the development of a firm texture that does not break down during mastication, unlike that observed in fullfat cheeses. The objective of this investigation was to determine how the amount of fat affects the structure of Cheddar cheese from initial formation (2 wk) through $24 \mathrm{wk}$ of aging. Cheeses were made with target fat contents of 3 to $33 \%$ (wt/wt) and moisture to protein ratios of 1.5:1. This allowed for comparisons based on relative amounts of fat and protein gel phases. Cheese microstructure was determined by confocal scanning laser microscopy combined with quantitative image analysis. Rheological analysis was used to determine changes in mechanical properties. Increasing fat content caused an increase in size of fat globules and a higher percentage of nonspherical globules. However, no changes in fat globules were observed with aging. Cheese rigidity (storage modulus) increased with fat content at $10^{\circ} \mathrm{C}$, but differences attributable to fat were not apparent at $25^{\circ} \mathrm{C}$. This was attributable to the storage modulus of fat approaching that of the protein gel; therefore, the amount of fat or gel phase did not have an effect on the cheese storage modulus. The rigidity of cheese decreased with storage and, because changes in the fat phase were not detected, it appeared to be attributable to changes in the gel network. It appeared that the diminished textural quality in low-fat Cheddar cheese is attributed to changes in the breakdown pattern during chewing, as altered by fat disrupting the cheese network.
\end{abstract}

Key words: cheese, low fat, microstructure, rheology

Received June 1, 2010.

Accepted June 24, 2010.

${ }^{1}$ Corresponding author: allen_foegeding@ncsu.edu

\section{INTRODUCTION}

The goal for an overall caloric reduction in the diet, sometimes specifically targeting calories from fat, has encouraged the development of low-fat alternatives to traditional products. Studies have shown that American consumers have a preference for lower fat dairy products, including cheese (Sandrou and Arvanitoyannis, 2000; Childs and Drake, 2009). Cheese is perceived as being high in fat and this discourages some consumers from including cheese in their diet, even though it is also a good source of dietary calcium (Johnson et al., 2009). However, because fat is a major contributor to flavor and textural quality of food products, reducing fat while maintaining sensory quality presents several challenges. Cheddar cheese contains about 32\% (wt/ wt) fat, and there exists a desire to produce a low-fat version with $\leq 6 \%$ fat that maintains sensory quality so as to allow its continued use in school lunch programs (Johnson et al., 2009).

Many reports have shown that as the fat content of cheese is progressively reduced, the cheese develops an undesirable firm, rubbery texture (Bryant et al., 1995; Guinee et al., 2000; Mistry, 2001; Gwartney et al., 2002; Rogers et al., 2009). Likewise, numerous strategies have been applied to improve the texture of low-fat cheese and these have been reviewed (Drake and Swanson, 1995; Mistry, 2001; Banks, 2004, 2007; Johnson et al., 2009). However, it still remains a challenge to reduce fat and maintain the texture of a comparable full-fat cheese.

Sensory textural properties of cheese are the result of the temporal pattern of structural breakdown and mixing with saliva during oral processing (Huttchings and Lillford, 1988). Therefore, when fat is removed, the low-fat structure needs to be altered such that it has a breakdown pattern and saliva interactions similar to that of full-fat cheese. Sensory texture terms can be separated into "first bite" and "chewdown" terms (Foegeding and Drake, 2007). First bite terms represent the initial deformation and fracture (e.g., firmness or hardness) of the cheese, and chewdown terms (e.g., degree of breakdown, cohesiveness, adhesiveness, and smoothness 
of mass) are determined after chewing and mixing with saliva. Reduced- and low-fat cheeses have increased first bite terms and decreased chewdown terms (Gwartney et al., 2002). Aging has a more dramatic effect on chewdown terms of Cheddar cheese, with sensory creaminess increasing from approximately 0.5 to 7 over 64 wk of aging and firmness changing only from 3.8 to 2.4 over the same period (relative values base on a $9-\mathrm{cm}$ line scale; Hort and Le Grys, 2001). Cheddar cheeses containing 5 or $16 \%$ (wt/wt) fat are firmer and lower in chewdown terms than those containing $32 \%$ (wt/wt) fat at 2 wk after manufacture (Rogers et al., 2009). Upon aging, the largest changes in sensory texture are seen within the first $3 \mathrm{mo}$, with increases in the chewdown terms strongly differentiating cheeses based on fat level (Rogers et al., 2009). Therefore, understanding initial structural differences and how structural elements change over time is needed to determine how low-fat cheese texture can be brought closer to that of full-fat cheese.

Cheese structure can be viewed as a continuous protein gel network disrupted with interdispersed fat globules. From a materials science perspective, this is a 2-phase material comprising a continuous protein gel phase (accounting for protein, water, and dissolved solids) with an interdispersed fat phase. This so-called "filled gel" model has been used to describe the role of fat in hard and semi-hard cheeses (Visser, 1991). The storage modulus $\left(\mathbf{G}^{\prime}\right)$ of a filled gel network is determined by gel network elasticity and phase volume $\left(\phi_{\text {gel }}\right)$, filler particle elasticity and phase volume $\left(\phi_{\text {filler }}\right)$, and interactions (or lack of) between the filler particle and the gel network (van Vliet, 1988; Dickinson and Chen, 1999; Sala et al., 2009). Stiffer filler particles produce a firmer material as a result of a reinforcing effect provided by the filler (Brownsey et al., 1987). This stiffening effect is seen in cheese and rennet casein gels where the firmness of the fat filler particles is affected by temperature (Visser, 1991; Zhou and Mulvaney, 1998).

Removal of fat is associated with a lower fat to protein ratio, resulting in a more dense protein structure, thus making the cheese firmer (Johnson and Chen, 1995). Density of cheese structure can be viewed from 2 perspectives. First, viewing overall cheese structure, a decrease in $\phi_{\text {filler }}$ will increase $\phi_{\text {gel }}$ when fat is reduced (note that $\phi_{\text {filler }}+\phi_{\text {gel }}=1$ ). Alternatively, or coinciding, a reduction in fat without a proportionate increase in water also will increase the concentration of protein in the gel phase. For most protein gels, an increase in protein concentration coincides with a more rigid (increased gel network elasticity) and stronger network because of a greater density of proteins in the network. This relationship was the case in the investigations of
Bryant et al. (1995) and Guinee et al. (2000), where a decrease in fat content coincided with a decrease in the moisture to protein ratio and an increase in cheese hardness. Likewise, Ustunol et al. (1995) showed that decreasing fat content (34 to $13 \%$ wt/wt) with a coinciding decrease in moisture to protein ratio caused an increase in the $\mathrm{G}^{\prime}$ of a filled gel network. Therefore, the combination of a decreased percentage of fat phase and increased protein concentration in the gel phase is expected to result in a firmer cheese based on filled gel considerations. However, this assumes that the only differences are in the amount of protein gel and fat phases and concentration of protein in the gel phase, without taking into account other factors determining gel network formation. Factors during processing, such as pH, will alter cheese texture and this reflects changes in the protein gel network (Johnson and Chen, 1995; Mistry, 2001). Besides composition and $\mathrm{pH}$, aging also plays a major role in cheese structure and texture. Cheese aging results from several processes, including protein hydrolysis and reequilibration of ions (Lawrence et al., 1987; Altemueller and Rosenberg, 1996; Fenelon et al., 2000; Guinee et al., 2000; Lucey et al., 2003; Banks, 2004, 2007). Reequilibration of ions and hydrolysis would affect all levels of protein structure (molecular mass to quaternary structures) and thereby alter the array of molecules available to form the gel network and their interactions.

The general approaches that have been used to improve low-fat cheese texture involve decreasing protein concentration (i.e., increasing moisture to protein ratio of the gel phase), causing greater hydrolysis of the proteins, altering protein-protein interactions, or creating a bigger filler phase (Drake and Swanson, 1995; Mistry, 2001; Banks, 2004, 2007; Johnson et al., 2009). Comparing among investigations, it is difficult to sort out the individual effects of $\mathrm{pH}$, proteolysis, and protein concentration because each tends to be convoluted when altering the fat content of cheese. This problem was noted by Zhou and Mulvaney (1998), who took the approach of making a model gel using rennet casein and unsalted butter to look at the effects of casein to water ratio and milk fat.

In a previous investigation, Cheddar cheeses were prepared with similar moisture to protein ratios $(\sim 1.5)$ and varying amounts of fat ( 5 to $32 \% \mathrm{wt} / \mathrm{wt}$ ) to examine the effect of a constant gel phase composition (Rogers et al., 2009). Although that investigation established changes in sensory texture and rheological properties, the limited range of fat content $(5,16$, and $32 \% \mathrm{wt} /$ wt), broad sampling times $(0.5,3,6$, and $9 \mathrm{mo})$, and lack of microstructure determination did not allow for establishing changes in cheese structure during the initial phase of aging. The objective of this investigation 
was to determine structural changes among Cheddar cheeses with a range of fat contents over $24 \mathrm{wk}$ of aging. Cheddar cheeses were made with target values of 3,8 , $13,18,23,28$, and $33 \%$ (wt/wt) fat. Changes in rheological and microstructural properties were measured at $2,4,8,12$, and 24 wk. A subsequent report will discuss large deformation, fracture, and sensory properties of the cheeses.

\section{MATERIALS AND METHODS}

\section{Cheddar Cheese Production}

Materials. A starter culture consisting of frozen pellets of a blend of Lactococcus lactis ssp. lactis/cremoris (DVS850) was obtained from Chr. Hansen Inc. (Milwaukee, WI). Double strength ( $\sim 650$ international milk clotting units $/ \mathrm{mL}$ ) chymosin rennet (Maxiren) and single strength annatto color were obtained from DSM Food Specialties USA Inc. (Eagleville, PA). Fresh cow's milk was obtained from Utah State University's Caine Dairy Research and Teaching Center (Wellsville, UT). Plastic hoop liners and bags (V7-400) were obtained from Vilutis and Co. Inc. (Frankfort, IL).

Cheese Manufacture. Cold milk was transported to the Gary Haight Richardson Dairy Products Laboratory at Utah State University (Logan) and 700-kg batches were standardized to protein to fat ratios described in Table 1 so as to obtain nominal fat levels of $3,8,13,18,23,28$, and $33 \%$ (wt/wt) in the cheese. The milk was pasteurized $\left(73^{\circ} \mathrm{C}\right.$ for $\left.15 \mathrm{~s}\right)$ and pumped into a Tetra Scherping horizontal cheese vat (Tetra Pak Cheese \& Powder Systems Inc., Winsted, MN) and heated to $31^{\circ} \mathrm{C}$. Starter culture was added at $20 \mathrm{~g} / 100$ $\mathrm{kg}$ of milk and annatto was added at $9 \mathrm{~mL} / 100 \mathrm{~kg}$ of milk, and the milk was allowed to ripen for $40 \mathrm{~min}$. The milk was set by chymosin using $8 \mathrm{~mL} / 100 \mathrm{~kg}$ of milk, stirred for $2 \mathrm{~min}$, and then allowed to coagulate without stirring until a firm set was reached (30 min).
Cheesemaking parameters were then varied based upon the fat level in the milk with the aim of increasing the moisture content as fat content decreased so as to maintain a constant moisture to protein ratio as well as a constant salt to moisture ratio in the final cheese. The curd was cut at $14 \mathrm{rpm}$ for up to $2 \mathrm{~min}$ as shown in Table 1, then gently agitated starting at 2, 3, 4, 5, and $6 \mathrm{rpm}$ for $1 \mathrm{~min}$ each to allow curd healing, and then stirring was increased to $14 \mathrm{rpm}$ over a 12 -min period. Fifty minutes after renneting, the curd and whey was heated at rates and temperatures shown in Table 1. After stirring for $35 \mathrm{~min}$ more, the curd and whey were pumped to a drain table (Kusel Equipment Co., Watertown, WI) and stirring continued until the curd $\mathrm{pH}$ reached 6.3 , and whey was drained. The curd was washed for 10 min with sufficient water (60 to 100 $\mathrm{kg}$ ) to adjust the curd temperature as shown in Table 1 and to remove a portion of lactose from the curd to prevent overacidification. After draining the water and whey, the curd was stirred until $\mathrm{pH} 5.90$ was reached, and the curd was weighed and salted at rates shown in Table 1 using 3 applications spaced 5 min apart. Twelve kilograms of salt curd was placed in plastic cheesecloth-lined stainless steel hoops and pressed at $80 \mathrm{kPa}$ overnight $(\sim 18 \mathrm{~h})$ at room temperature $\left(\sim 20^{\circ} \mathrm{C}\right)$ into nominal $10-\mathrm{kg}$ blocks. The cheeses were vacuumed packaged and then stored at $6^{\circ} \mathrm{C}$ for aging. Cheese was manufactured on individual days and 2 replications of each cheese were produced. The cheeses were kept at Utah State University for aging at $8^{\circ} \mathrm{C}$ for 6 mo. Sample blocks were shipped to North Carolina State University at 2, 4, 8, 12, and 24 wk of age for testing. Two complete replications of cheeses were made.

\section{Proximate Analysis}

Moisture content was determined in triplicate by weight loss using a microwave oven (CEM Corp., Indian Trail, NC) at $70 \%$ power with an endpoint set-

Table 1. Manufacturing parameters modified to obtain similar moisture-to-protein and salt-to-moisture ratios in Cheddar cheese targeted at containing $3,8,13,18,23,28$, and $33 \%$ (wt/wt) fat

\begin{tabular}{lccccccc}
\hline & \multicolumn{7}{c}{ Target cheese fat content, $\%$} \\
\cline { 2 - 8 } Parameter & \multicolumn{1}{c}{3} & 8 & 13 & 18 & 23 & 28 & 33 \\
\hline Milk fat level, g/100 g & 0.4 & 0.9 & 1.4 & 2.0 & 2.3 & 3.1 & 3.7 \\
Milk protein to fat ratio & 6.6 & 3.5 & 2.3 & 3.3 & 1.4 & 1.0 & 0.83 \\
Cutting revolutions ${ }^{\circ}$ & 14 & 18 & 21 & 21 & 21 & 21 & 42 \\
Heating rate, ${ }^{\circ} \mathrm{C} / \mathrm{min}$ & 0.26 & 0.30 & 0.30 & 0.33 & 0.28 & 0.27 & 0.22 \\
Cooking temperature, ${ }^{\circ} \mathrm{C}$ & 35 & 36 & 36 & 36 & 37 & 38 & 39 \\
Set-to-drain time, min & 107 & 107 & 125 & 125 & 130 & 135 & 145 \\
Wash water temperature, ${ }^{\circ} \mathrm{C}$ & 15 & 17 & 16 & 17 & 18 & 20 & 21 \\
Curd wash temperature, ${ }^{\circ} \mathrm{C}$ & 25 & 26 & 27 & 28 & 28 & 30 & 31 \\
Set-to-salt time, min & 180 & 180 & 180 & 180 & 180 & 185 & 195 \\
Salt, g/kg of curd & 29 & 27 & 27 & 26 & 25 & 24 & 22 \\
\hline
\end{tabular}

${ }^{1}$ Number of vat agitator revolutions at $14 \mathrm{rpm}$ during curd cutting mode. 
ting of $<0.4 \mathrm{mg}$ of weight change over $2 \mathrm{~s}$. Fat content was determined in duplicate using a modified Babcock method (Richardson, 1985). Salt was measured by homogenizing grated cheese with distilled water for $4 \mathrm{~min}$ at $260 \mathrm{rpm}$ in a Stomacher 400 (Seward, Worthing, UK). The slurry was filtered through a Whatman \#1 filter paper, and the filtrate was analyzed for sodium chloride using a chloride analyzer (model 926, Corning, Medfield, MA). The $\mathrm{pH}$ was measured using a glass electrode after stomaching $20 \mathrm{~g}$ of grated cheese with 10 $\mathrm{g}$ of distilled water for $1 \mathrm{~min}$ at $260 \mathrm{rpm}$. Protein was calculated from $\mathrm{N}$ measured by combustion (triplicate samples) and multiplied by 6.38 .

\section{Rheological Analysis}

Determination of Linear Viscoelastic Region. Stress sweeps of cheeses were done at $25^{\circ} \mathrm{C}$ using a Stress Tech controlled stress rheometer (ATS Rheosystems, Bordentown, NJ) fitted with a $20-\mathrm{mm}$ smooth parallel plate geometry, according to the method of Rogers et al. (2009). The cheese samples were sliced $4 \mathrm{~mm}$ thick, trimmed to the size of the plate, and glued to both plates to prevent slip using cyanoacrylate glue (Loctite 401, Loctite Corp., Rocky Hill, CT). A thin layer of synthetic lubricant (SuperLube, Synco Chemical, Bohemia, NY) was applied to exposed edges of the sample to minimize sample dehydration during testing. Tests were conducted at $10 \mathrm{~Hz}$ with a stress range from 1 to $1,000 \mathrm{~Pa}$ on each cheese for each replication. The limit of the linear viscoelastic region was defined as the point where consecutive measurements (taken every $26.3 \mathrm{~s}$ ) showed decreasing complex modulus $\left(\mathrm{G}^{*}\right)$ in sequential measurements.

Controlled Temperature Frequency Sweeps. Frequency sweeps for all cheeses were conducted within the linear viscoelastic region using the basic rheometer conditions and sample preparation described above. Sweeps were conducted from 0.1 to $10 \mathrm{~Hz}$ at $150 \mathrm{~Pa}$. All cheeses were tested at 4 controlled temperatures (10, 15,20 , and $25 \pm 0.1^{\circ} \mathrm{C}$ ). Only 2 decades of frequency were used because the testing time required for 3 or more decades was not possible within the timeframe to analyze all treatments at one sampling time.

\section{Microstructural Analysis}

Microscopy. Cheese microstructure was imaged using confocal scanning laser microscopy (CSLM). The method for imaging cheese samples with CSLM was based on that of Auty et al. (2001). Cheese samples were kept at $10^{\circ} \mathrm{C}$ until sliced into sections approximately $5 \mathrm{~mm} \times 5 \mathrm{~mm} \times 1 \mathrm{~mm}$ thick using a razor blade. Fluorescent dyes Nile Red and Rhodamine B

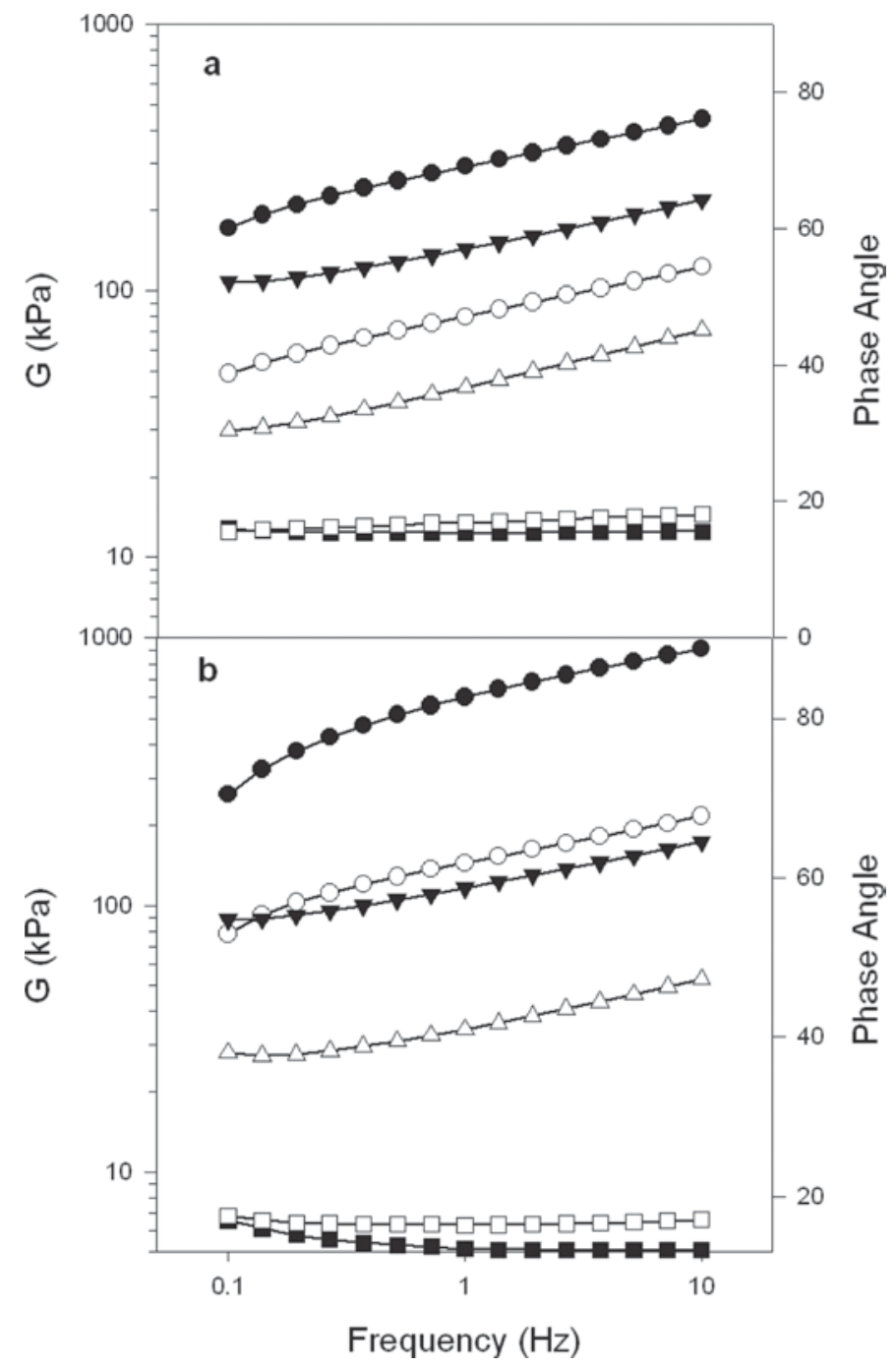

Figure 1. Mechanical spectra for cheeses containing 3.0\% (a) and $33.0 \%$ fat (b). Properties at $10^{\circ} \mathrm{C}:-=$ storage modulus $\left(\mathrm{G}^{\prime}\right), \mathrm{O}=$ loss modulus $\left(\mathrm{G}^{\prime \prime}\right)$, and $\mathbf{\square}=$ phase angle. Properties at $25^{\circ} \mathrm{C}: \boldsymbol{\nabla}=\mathrm{G}^{\prime}, \Delta$ $=\mathrm{G}^{\prime \prime}$, and $\square=$ phase angle.

(Invitrogen Molecular Probes, Eugene, OR) were used to image the fat and protein phases of the cheese, respectively. The dyes were pipetted on the cut surface of the cheese: $15 \mu \mathrm{L}$ of Nile Red solution ( $2 \%$ solids) and $15 \mu \mathrm{L}$ of Rhodamine B solution $(0.2 \% \mathrm{wt} / \mathrm{vol}$ in deionized water). Samples stood for at least $10 \mathrm{~min}$ to absorb the dyes and return to room temperature. Cheese samples were then inverted onto a single-welled slide with a \#1.5 coverslip attached to the bottom with silicone grease. Samples were imaged using an inverted Leica TCS SP1 CSLM using a PL Fluotar $40.0 \times 1.0$ oil UV objective (Leica Microsystems GmbH, Wetzlar, Germany). A zoom of $2.5 \times$ was used, resulting in a field size of $100 \mu \mathrm{m} \times 100 \mu \mathrm{m}$. Excitation of the sample was performed using a 488-nm laser (fat phase) and 
a 561-nm laser (protein phase) sequentially. For each cheese treatment, 2 samples were prepared and $5 \mathrm{im}$ ages were taken per sample, resulting in 10 images per treatment.

Image Analysis. Confocal scanning laser microscopy images of the fat phase of cheese samples were analyzed using Metamorph Imaging System software (Molecular Devices, Downingtown, PA). The area of each fat globule was measured and the shape factor was calculated, which was defined as follows: shape factor $=4 \pi$ area $/$ perimeter $^{2}$. A shape factor of 1 indicated a perfect sphere, whereas lower shape factors showed a deviation from roundness. Fat globules touching the edge of the frame were eliminated from analysis.

\section{RESULTS AND DISCUSSION}

\section{Proximate Analysis}

Actual fat levels were very close to target levels (Table 2). The most different were the $13 \%$ (15.5\% actual) and $18 \%$ (20.3\% actual) cheeses. Because the goal was to provide a range of fat levels rather than precise fat levels, these differences did not alter the investigation. All fat levels presented in figures are actual values. The moisture to protein ratio was very similar among cheeses, ranging from 1.41:1 to 1.69:1, with an average of 1.57:1 (Table 2). This coincides well with our previous investigation that ranged from 1.5: 1 to 1.6:1 and an average of 1.53:1 (Rogers et al., 2009). This similarity allowed for application of the filled gel model where the differences in composition are primarily attributed to the amount of gel (water and protein) and fat phase. However, it should be noted that changes within the gel phase were not measured.

\section{Rheological Properties}

The mechanical spectra provides a rheological fingerprint of the cheeses by presenting elastic $\left(\mathrm{G}^{\prime}\right)$ and viscous (loss modulus; $\mathbf{G}^{\prime \prime}$ ) elements as a function of time (frequency; Figure 1). The overall spectra for 3\% (Figure 1a) and 33\% (Figure 1b) fat were similar; show- ing an increase in $\mathrm{G}^{\prime}$ and $\mathrm{G}^{\prime \prime}$ as frequency increased and maintaining the relative magnitude of $\mathrm{G}^{\prime}>\mathrm{G}^{\prime \prime}$ (as seen in the relatively constant values for phase angle). This response is a characteristic pattern of a viscoelastic gel, where frequency-dependent moduli are observed, whereas the overall phase angle remains relatively unchanged. Because the major changes in $\mathrm{G}^{\prime}$ between 10 and $25^{\circ} \mathrm{C}$ coincided with minimal change in phase angle, and phase angle remained $<20^{\circ}$, differences were attributed to the general stiffness of the network rather than a melting transition (i.e., no fluid to solid transition observed). Similar transitions were observed by Lucey et al. (2003). Therefore, it appears that the overall softening of cheese with increased temperature is attributed to a combined melting (at least to a degree) of the dispersed fat and weakening of the gel network but no overall melting at 10 to $25^{\circ} \mathrm{C}$. This observation is consistent with temperature effects observed with a model casein gel made from rennet casein filled with milk fat from butter (Zhou and Mulvaney, 1998).

The mechanical spectra of cheeses varied with temperature, age, and fat content. At $10^{\circ} \mathrm{C}$, the $\mathrm{G}^{\prime}$ values were generally higher at 2 than 24 wk (Figure 2). By 24 wk, the $G^{\prime}$ values showed a general trend of increasing with fat content; however, some cheeses had different fat content but similar $\mathrm{G}^{\prime}$ values (e.g., 8.5, 15.5, and $20.3 \%$ wt/wt fat cheeses; Figure 2b). If we assume that the rheological properties of milk fat are similar among treatments and would therefore scale by fat level, then the lack of a clear scaling of cheese $\mathrm{G}^{\prime}$ values with fat content at $10^{\circ} \mathrm{C}$ likely reflects differences in the gel phase. However, when cheeses were measured at $25^{\circ} \mathrm{C}$, a reasonable temperature for oral processing, the differences among fat levels were minimal. The cheeses showed minor differences at $2 \mathrm{wk}$ (Figure 2c) and no major differences at $24 \mathrm{wk}$ (Figure 2d). This behavior was explored further by looking at how $\mathrm{G}^{\prime}$ changed with temperature at the 4 different aging times (Figure 3). A major decrease in $\mathrm{G}^{\prime}$ occurred as temperature increased from 10 to $15^{\circ} \mathrm{C}$, and all values among treatments started to converge at $20^{\circ} \mathrm{C}$ and were very similar at $25^{\circ} \mathrm{C}$. This temperature behavior can be attributed

Table 2. Compositional analysis of cheese

\begin{tabular}{lccccc}
\hline \multicolumn{2}{c}{ Fat content } & & & & \\
\cline { 1 - 2 } $\begin{array}{l}\text { Target } \\
(\% \text { wt/wt })\end{array}$ & $\begin{array}{c}\text { Actual } \\
(\% \mathrm{wt} / \mathrm{wt})\end{array}$ & $\begin{array}{c}\text { Moisture content } \\
(\% \mathrm{wt} / \mathrm{wt})\end{array}$ & $\begin{array}{c}\text { Moisture to } \\
\text { protein ratio }\end{array}$ & $\begin{array}{c}\text { Protein content } \\
(\% \mathrm{wt} / \mathrm{wt})\end{array}$ & $\mathrm{pH}$ \\
\hline 3.0 & 3.0 & 53.0 & $1.65: 1$ & 32.2 & 5.4 \\
8.0 & 8.5 & 49.6 & $1.41: 1$ & 35.2 & 5.3 \\
13.0 & 15.5 & 46.8 & $1.58: 1$ & 29.6 & 5.6 \\
18.0 & 20.3 & 45.4 & $1.69: 1$ & 26.9 & 5.5 \\
23.0 & 23.0 & 43.4 & $1.56: 1$ & 27.8 & 5.4 \\
28.0 & 28.8 & 30.0 & $1.52: 1$ & 26.3 & 5.5 \\
33.0 & 33.0 & 37.5 & $1.56: 1$ & 24.1 & 5.5 \\
\hline
\end{tabular}




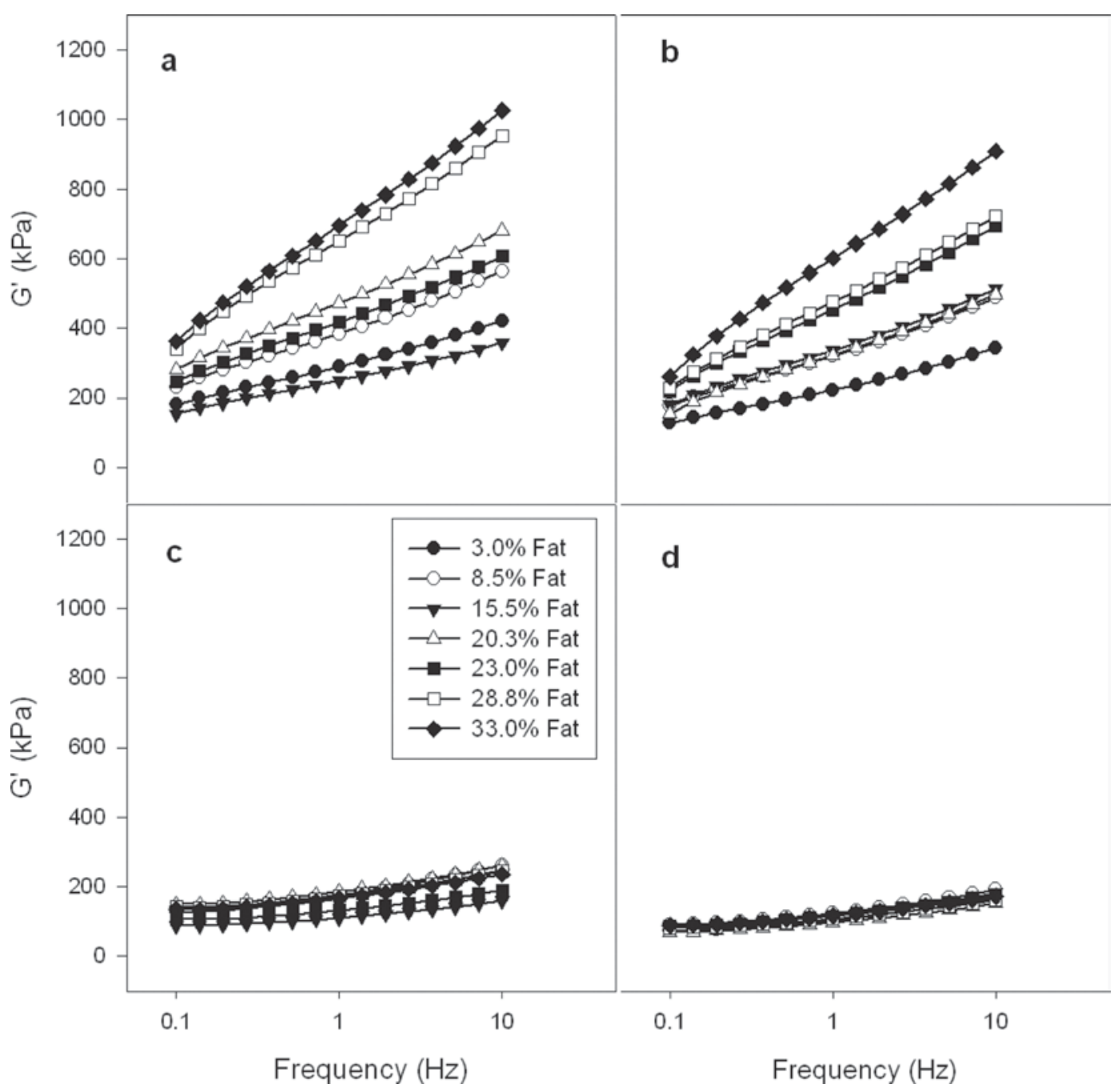

Figure 2. Storage modulus $\left(\mathrm{G}^{\prime}\right)$ of Cheddar cheeses of various fat contents over a range of frequencies, showing lowest $\left(10^{\circ} \mathrm{C}\right)$ and highest $\left(25^{\circ} \mathrm{C}\right)$ temperature for both $2 \mathrm{wk}\left(\mathrm{a}, 10^{\circ} \mathrm{C} ; \mathrm{c}, 25^{\circ} \mathrm{C}\right)$ and $24 \mathrm{wk}\left(\mathrm{b}, 10^{\circ} \mathrm{C} ; \mathrm{d}, 25^{\circ} \mathrm{C}\right)$ of aging.

to the solid to fluid phase change of the fat in the cheese (Gliguem et al., 2009; Vithanage et al., 2009) and alterations in the protein network. Visser (1991) also described this behavior, where differences in the range of 14 to $26^{\circ} \mathrm{C}$ were attributed to change in rigidity of the fat particles because of crystallization. However, it is seen that the lowest fat cheeses (3 to $15 \%$ wt/ wt) have a fairly linear decrease in $\mathrm{G}^{\prime}$ as temperature increases, suggesting a contribution mainly from the gel network. This coincides to $\mathrm{G}^{\prime}$ transitions observed in comparing low- and full-fat cream cheese (Brighenti et al., 2008). Whereas there is variation with age, a break point between 20.3 and $23.0 \%$ (wt/wt) fat was observed regarding temperature-induced changes in the elasticity of the cheese network.

Changes in $\mathrm{G}^{\prime}$ were grouped by fat and protein contents to determine which property best represented the cheeses (Figure 4). At $10^{\circ} \mathrm{C}$, a higher fat, lower protein content resulted in a higher storage modulus (Figure 4a, b), supporting the idea that the fat is dominating the rheological properties at this temperature. These differences were markedly reduced when the temperature was increased $25^{\circ} \mathrm{C}$ (Figure 4c, d). The network rigidity was highly dependent on temperature and shows the importance of matching temperatures when comparing mechanical and sensory evaluation of texture. Moreover, it shows that temperature and moisture to protein ratio, rather than protein content per se, determines the overall firmness of Cheddar cheese.

\section{Microstructure}

Cheeses from replications 1 and 2 exhibited very similar microstructures, so all images presented are 


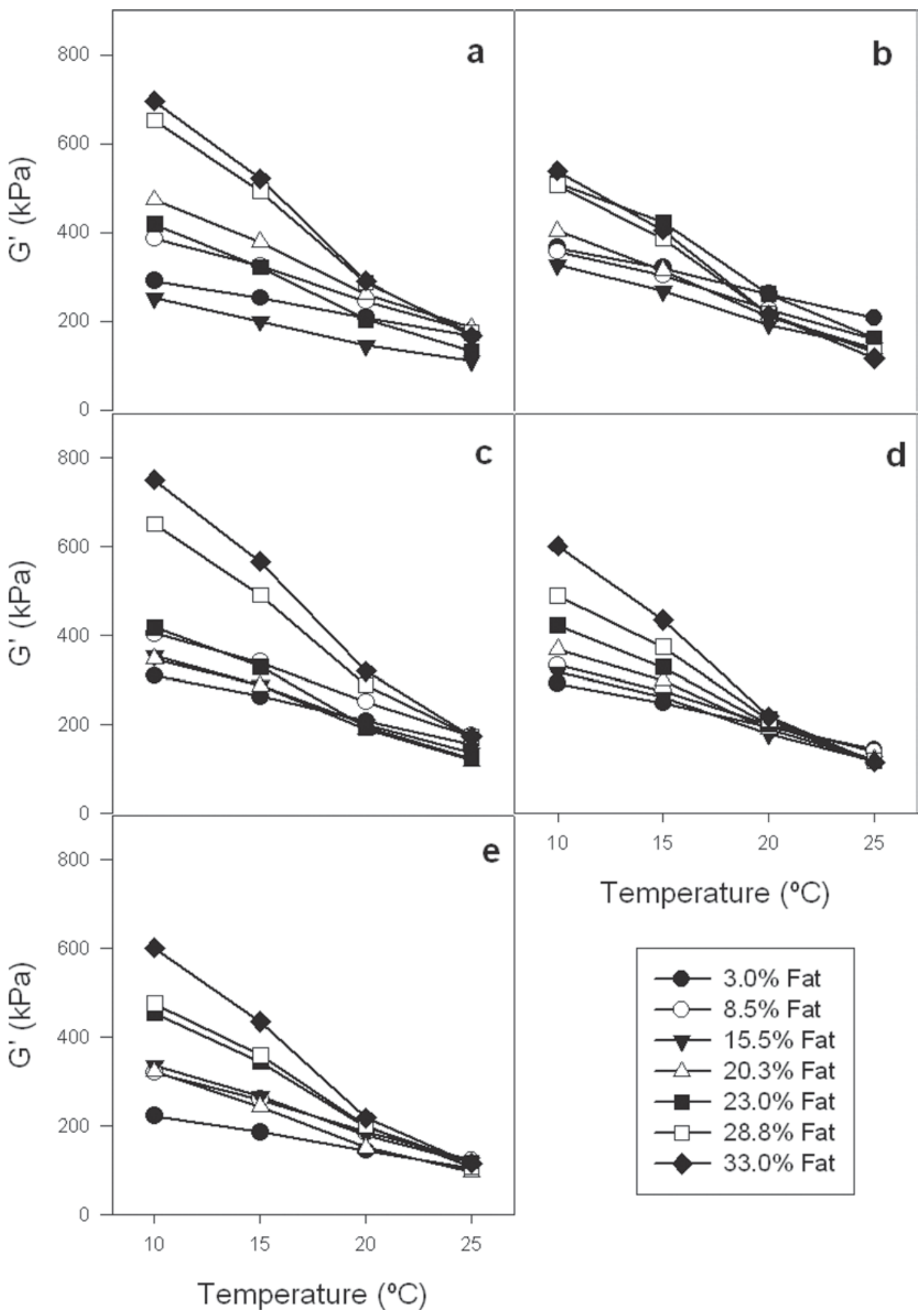

Figure 3. Storage modulus $\left(\mathrm{G}^{\prime}\right)$ of Cheddar cheeses of varying fat contents and temperatures. Values were determined at $1 \mathrm{~Hz}$ at $2 \mathrm{wk}(\mathrm{a})$, $4 \mathrm{wk}(\mathrm{b}), 8 \mathrm{wk}(\mathrm{c}), 12 \mathrm{wk}(\mathrm{d})$, and $24 \mathrm{wk}(\mathrm{e})$ of aging. 


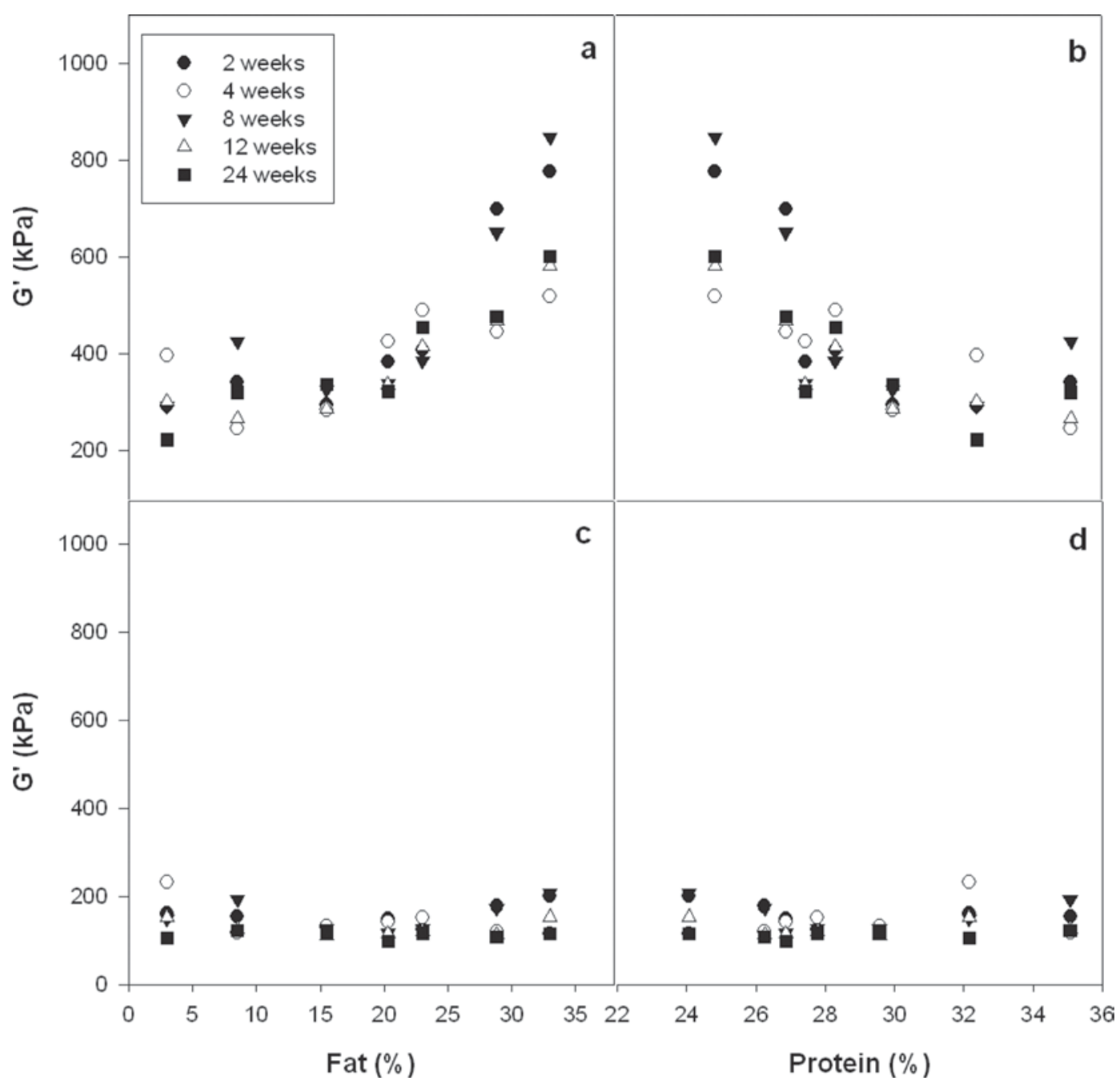

Figure 4. Storage modulus $\left(\mathrm{G}^{\prime}\right)$ of Cheddar cheeses with respect to fat (a) and protein (b) contents at $10^{\circ} \mathrm{C}$ and fat (c) and protein (d) contents at $25^{\circ} \mathrm{C}$ and measured at $1 \mathrm{~Hz}$.

from replication 1 and are representative of each treatment. Numerous features were observed in the Cheddar cheeses that correlate with previously reported cheese microstructure. Curd junctions could be visualized in some microstructural images (Figure 5). When the curd is cut, fat globules tend to separate from the surface of the curd during washing, leaving a protein-rich surface. Curds are subsequently pressed together and, when fused, form curd junctions with a high density of protein matrix and very little fat (Kalab et al., 1982). A micrograph of a curd junction is shown in row A of Figure 5, which is similar to curd junctions imaged in Emmental cheese using CSLM (Lopez et al., 2007). Previous studies have identified 4 forms of fat present in Emmental cheese: 1) intact milk fat globules; 2) aggregates or clusters of milk fat globules; 3) coalesced milk fat globules, resulting in a large globule, and 4) nonglobular fat or free fat (Lopez et al., 2007). Similar forms of fat were seen in images of Cheddar cheese, which are identified in Figure 5. Intact milk fat globules are the small, spherical globules dispersed throughout cheeses, especially visible in the lower fat cheeses. Aggregates of milk fat globules appear as clumps of circular globules (row B of Figure 5), whereas coalesced globules are spherical but larger than typical milk fat globules (row $\mathrm{C}$ of Figure 5). Nonglobular fat appears in the highest fat content cheeses, identifiable as large, nonspherical fat areas in the cheese (row D of Figure $5)$.

The CSLM images of cheese microstructure showed increasing fat globule size with increasing cheese fat content (Figure 6) and also showed changes in the shape of fat globules. Low-fat cheeses (3 and $8 \% \mathrm{wt} / \mathrm{wt}$ fat) had more spherical fat globules dispersed through- 
out the protein matrix; in contrast, fat globules in the highest fat cheeses (28 and $33 \%$ wt/wt fat) appear clumped and coalesced into nonspherical shapes. This observation is consistent with previous observations of Cheddar cheeses with varying fat levels (Guinee et al.,

A
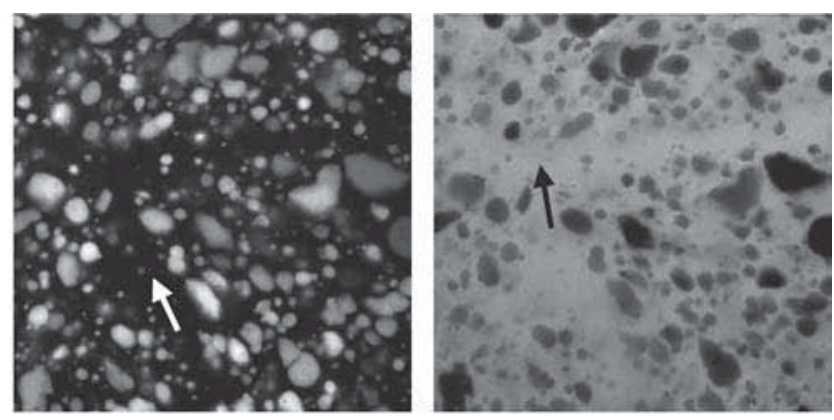

B
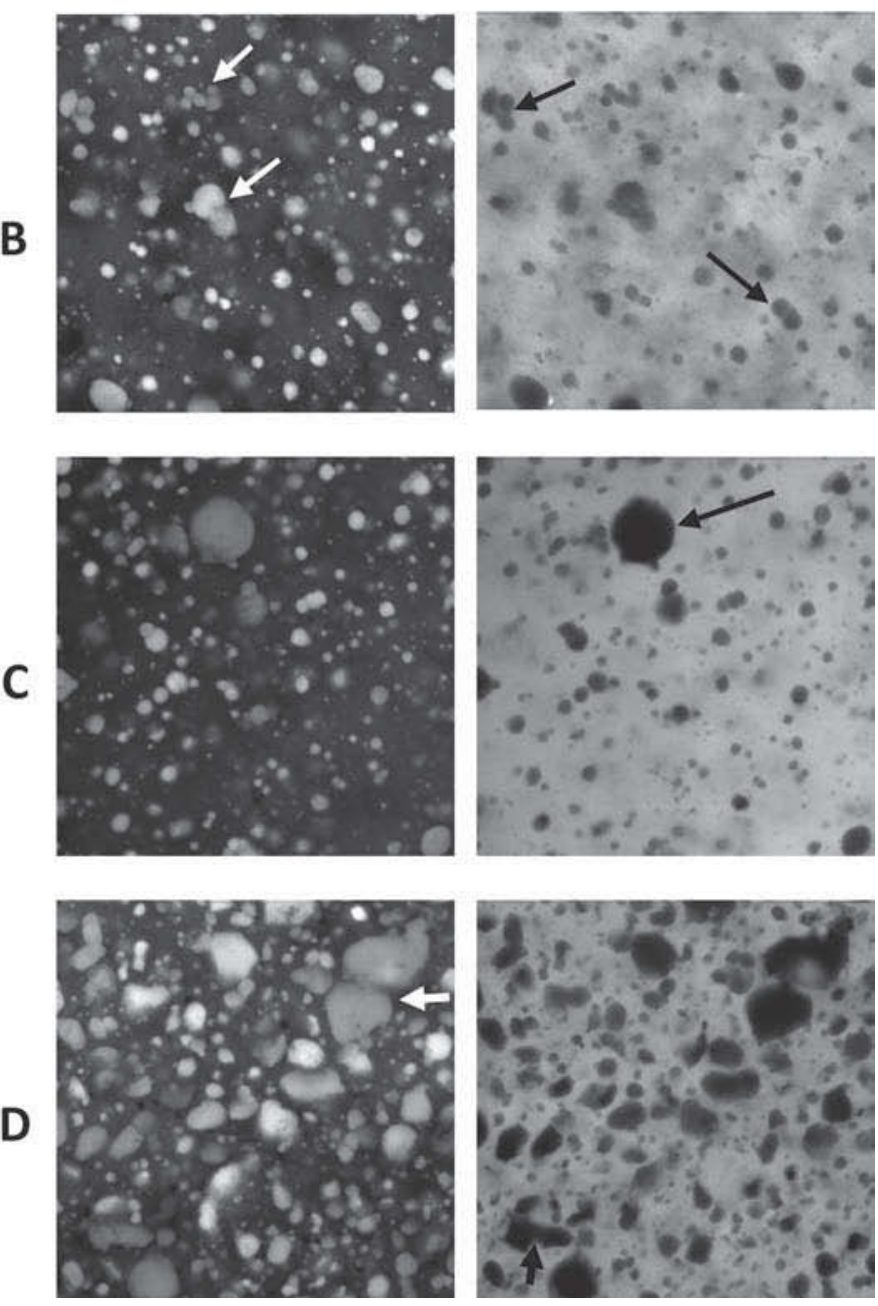

Figure 5. Confocal scanning laser microscopy images for Cheddar cheese showing examples of cheese features. All images show the fat (left) and protein (right) phases as bright against a dark background. Curd junctions (row A), aggregated fat globules (row B), coalesced fat globules (row C), and nonglobular fat (row D) are identified with arrows. Field size is $100 \mu \mathrm{m} \times 100 \mu \mathrm{m}$ for each image.
2000). Increasing size of the fat globules was attributed to shearing effects during the milk handling and cheesemaking processes, causing a rupture in the milk fat globule membrane and coalescence (Guinee et al., 2000). Image analysis allowed for measuring the changes seen in milk fat globules. Changes in mean shape factor and fat globule area were consistent with fat globules getting larger and less spherical as fat content increased from 3.0 to $33.0 \%$ (wt/wt) fat (Figure 7 ). The shape factor distribution provides more information on fat globule morphology change. Spherical particles represented 42 to $47 \%$ of the particles in cheeses with 3 or $8.5 \%$ fat whereas they accounted for only 26 to $30 \%$ of the fat in cheeses at 23 to $33 \%$ fat. In contrast, the least spherical particles (shape factor $<0.9$ ) accounted for 34 to $47 \%$ in the lower fat cheeses (3 or $8.5 \% \mathrm{wt} / \mathrm{wt}$ fat) and 62 to $70 \%$ in higher fat cheeses (23 to $33 \%$ wt/ wt fat). Because a spherical geometry has the lowest surface areas to volume, the transition to less spherical fat globules in higher fat cheeses adds to the increase in fat-protein interfacial area. However, total surface area at a fixed volume would increase as spherical diameter decreased, so it is difficult to say whether higher fat content has greater fat surface area.

Aging of the cheese did not result in major changes in the cheese microstructure; images were similar for all treatments across aging time (2 to 24 wk; Figure 8). Minimal changes in microstructure over time could be expected because the fat phase would be mainly solid and less prone to clumping or coalescence at the storage temperature of $8^{\circ} \mathrm{C}$ (Guinee et al., 2000). Therefore, the overall decrease in $\mathrm{G}^{\prime}$ with aging is most likely attributable to changes in the protein network and not to changes in the dispersed fat phase.

\section{Major Structural Changes Associated with Fat Reduction}

Previous investigations (e.g., Bryant et al., 1995; Guinee et al., 2000) have reduced the fat content of Cheddar cheese and not held the moisture to protein ratio constant. This resulted in increased protein concentration in the gel phase as the amount of fat (filler phase) was decreased and an increase in $\mathrm{G}^{\prime}$ (Ustunol et al., 1995). Therefore, cheese firmness was related to decreasing the amount of fat and increasing protein concentration in the gel phase. In our investigation, changes in the filler phase volume were apparent in the microstructure, along with rheological properties determined at 10 and $15^{\circ} \mathrm{C}$. The combination of fat melting and the casein gel weakening made the rigidities of the cheeses roughly equivalent at $25^{\circ} \mathrm{C}$. Our effects of temperature on $\mathrm{G}^{\prime}$ of Cheddar cheese are very similar to those Zhou and Mulvaney (1998) observed 


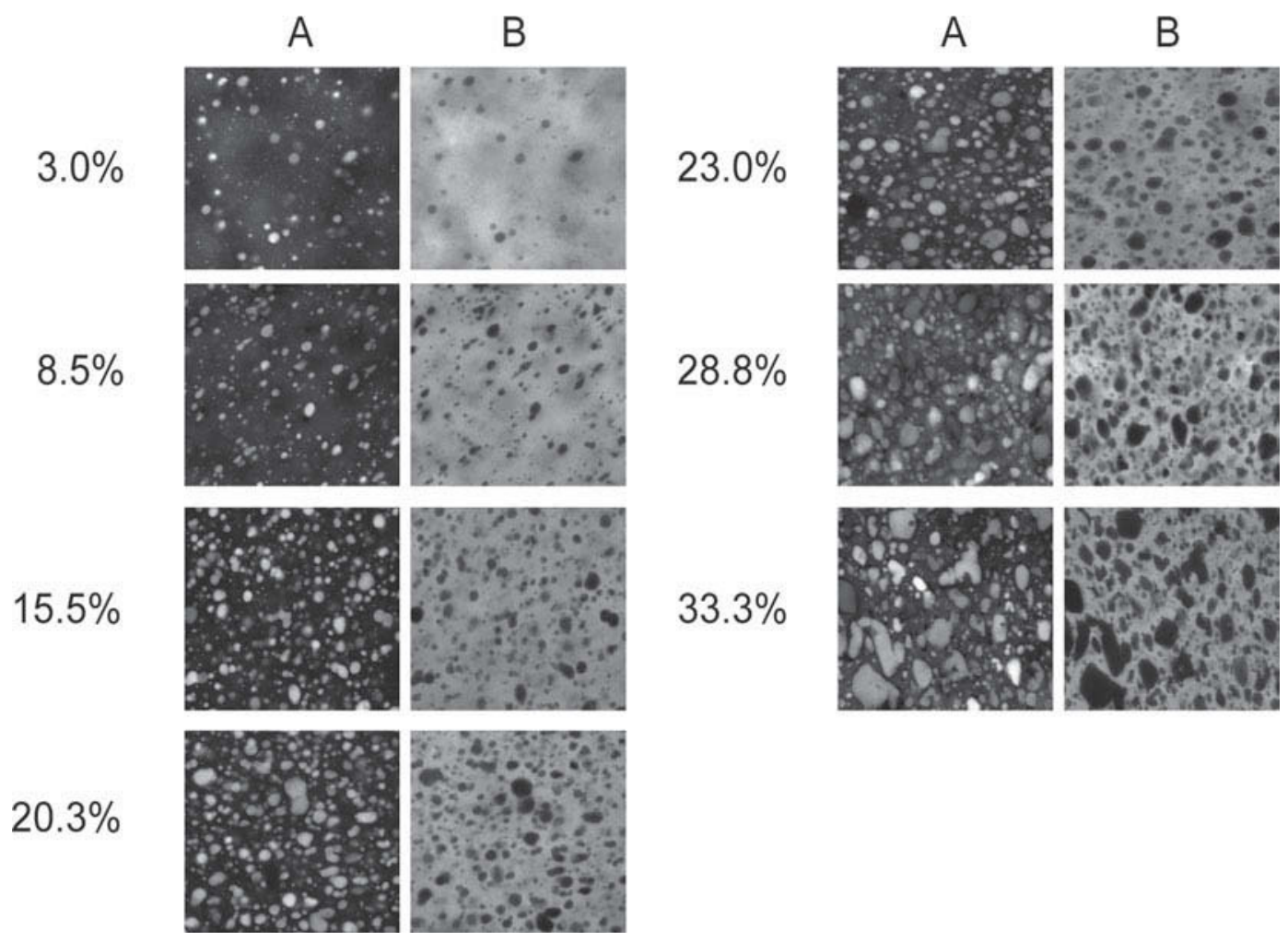

Figure 6. Confocal scanning laser microscopy images for all fat contents for Cheddar cheese at 12 wk of age. Column A represents the fat phase and column B represents the protein phase of the cheeses. Field size is $100 \mu \mathrm{m} \times 100 \mu \mathrm{m}$ for each image.

with casein gels. They showed a neutral fat effect at 20 to $25^{\circ} \mathrm{C}$ and a weakening at higher temperatures. Therefore, the contribution of fat to $\mathrm{G}^{\prime}$ will progress from positive to neutral to negative as fat moves from the solid to the liquid state (Zhou and Mulvaney, 1998; Gliguem et al., 2009). However, maintaining moisture to protein ratio in the gel phase and decreasing fat content still produces cheese with undesirable textural properties (Rogers et al., 2009).

\section{CONCLUSIONS}

The basic model for sensory texture proposed by Huttchings and Lillford (1988) indicates that a starting "structure" is broken down during mastication and mixed with saliva for lubrication and bolus formation. These processes determine sensory texture. When the moisture to protein ratio was held constant, no differences were found in the structures of Cheddar cheeses containing 3 to $33 \%$ fat at $25^{\circ} \mathrm{C}$, as indicated by similar rheological properties (magnitude of $\mathrm{G}^{\prime}$ and frequency dependence). However, the magnitude of $\mathrm{G}^{\prime}$ decreased over time, indicating a change in the fine structure of the protein network (i.e., changes at the nano scale). In contrast, clear differences were observed in microstructure at the micrometer level regarding fat, with differ- ences in amount, size, and shape of fat globules but no age-associated changes. It would appear that the textural properties of Cheddar cheese depend on how the initial distribution of fat globules, and changes in

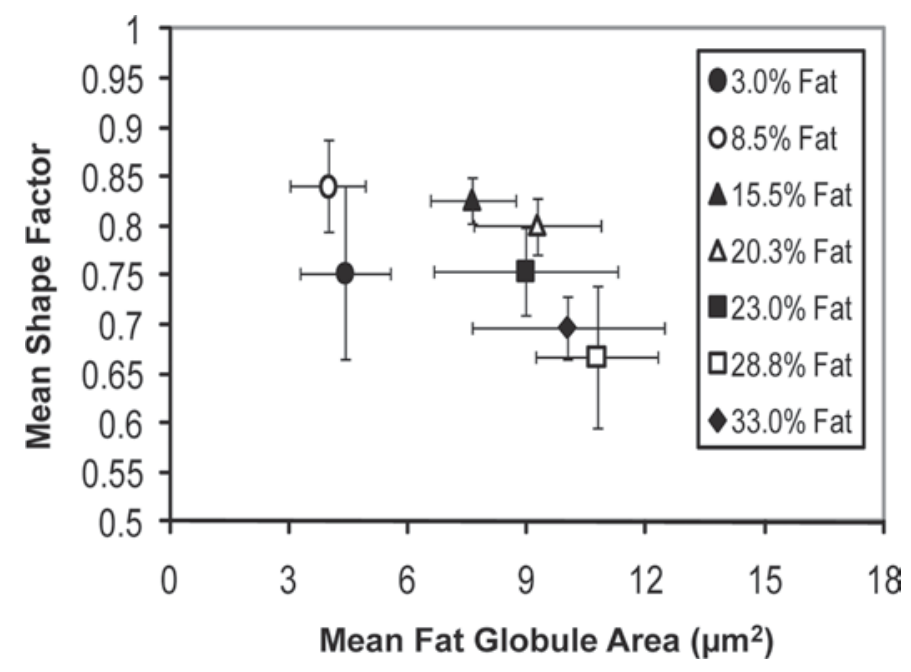

Figure 7. Image analysis results from confocal scanning laser microscopy images showing mean fat globule shape factor and area for cheeses aged 12 wk. Error bars represent 1 standard deviation above and below the mean. 


\section{$3 \%$ fat}

A

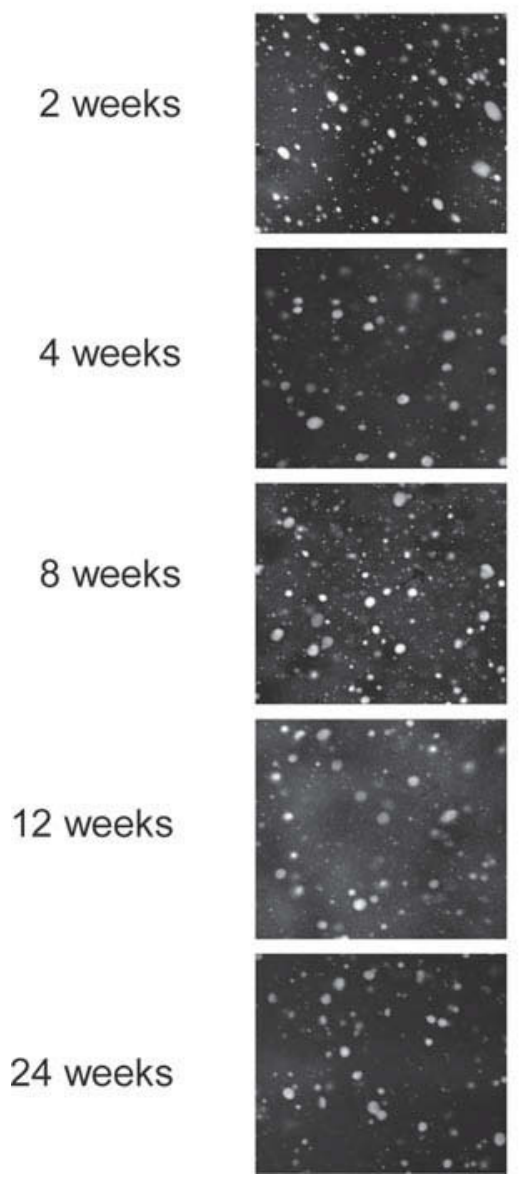

$3 \%$ fat

B
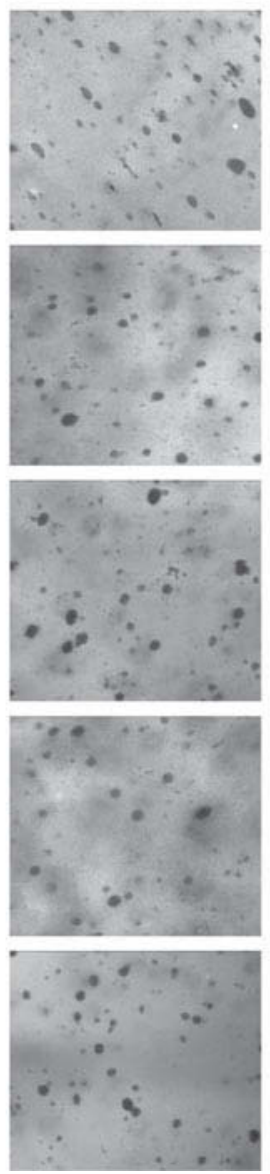

$33 \%$ fat

A
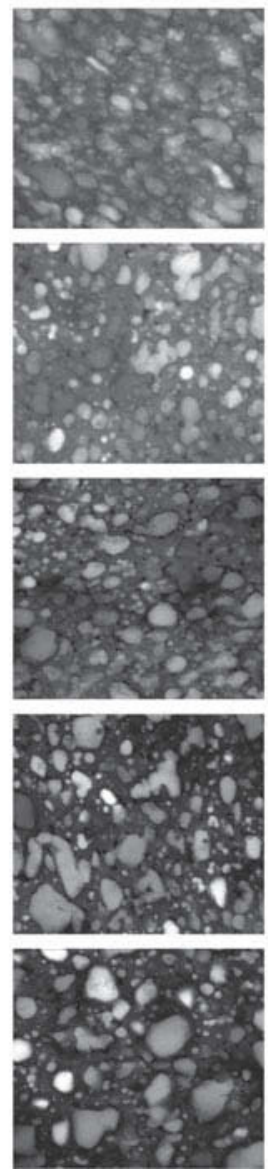

$33 \%$ fat

B
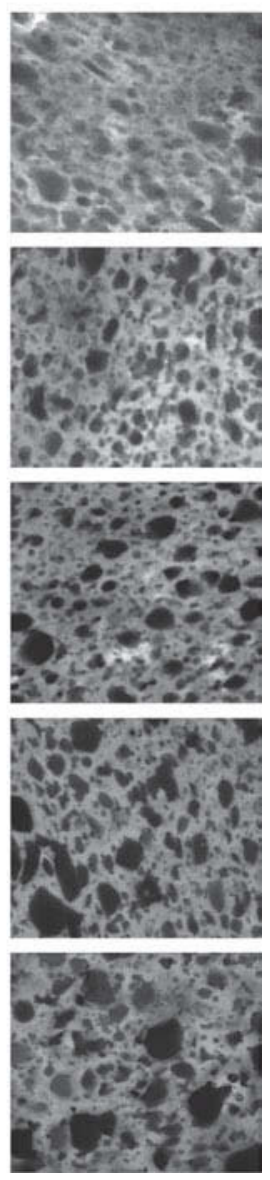

Figure 8. Confocal scanning laser microscopy images for Cheddar cheeses at 3.0 and $33.0 \%$ fat content at 2, 4, 8, 12, 24 wk of aging. Column A represents the fat phase and column B represents the protein phase. Field size is $100 \mu \mathrm{m} \times 100 \mu \mathrm{m}$ for each image.

the protein gel network over time, alter the breakdown pathway and particle lubrication during oral processing.

\section{ACKNOWLEDGMENTS}

Paper no. FSR-10-12 of the Journal Series of the Department of Food, Bioprocessing and Nutrition Science, North Carolina State University, Raleigh. Support from the North Carolina Agricultural Research Service (Raleigh) and Dairy Management Inc. (Rosemont, IL) are gratefully acknowledged.

\section{REFERENCES}

Altemueller, A. G., and M. Rosenberg. 1996. Monitoring proteolysis during ripening of full-fat and low-fat Cheddar cheese by reversephase HPLC. J. Food Sci. 61:295-298.

Auty, M. A. E., M. Twomey, T. P. Guinee, and D. M. Mulvihill. 2001. Development and application of confocal scanning laser micros- copy methods for studying the distribution of fat and protein in selected dairy products. J. Dairy Res. 68:417-427.

Banks, J. M. 2004. The technology of low-fat cheese manufacture. Int. J. Dairy Tech. 57:199-207.

Banks, J. M. 2007. What general factors affect the texture of hard and semi-hard cheeses? Pages 200-201 in Cheese Problems Solved. P. L. H. McSweeney, ed. Woodhead, Boca Raton, FL.

Brighenti, M., S. Govindasamy-Lucey, K. Lim, K. Nelson, and J. A. Lucey. 2008. Characterization of the rheological, textural, and sensory properties of samples of commercial US cream cheese with different fat contents. J. Dairy Sci. 91:4501-4517.

Brownsey, G. J., H. S. Ellis, M. J. Ridout, and S. G. Ring. 1987. Elasticity and failure in composite gels. J. Rheology 31:635-649.

Bryant, A., Z. Ustunol, and J. Steffe. 1995. Texture of Cheddar cheese as influenced by fat reduction. J. Food Sci. 60:1216-1219.

Childs, J. L., and M. A. Drake. 2009. Consumer perceptions of fat reduction in cheese. J. Sens. Stud. 24:902-921.

Dickinson, E., and J. Chen. 1999. Heat-set whey protein emulsion gels: Role of active and inactive filler particles. J. Disp. Sci. and Technol. 20:197-213.

Drake, M. A., and B. G. Swanson. 1995. Reduced and low fat cheese technology: A review. Trends Food Sci. Technol. 6:366-369.

Fenelon, M. A., P. O'Connor, and T. P. Guinee. 2000. The effect of fat content on the microbiology and proteolysis in Cheddar cheese during ripening. J. Dairy Sci. 83:2173-2183. 
Foegeding, E. A., and M. A. Drake. 2007. Sensory and mechanical properties of cheese texture. J. Dairy Sci. 90:1611-1624.

Gliguem, H., D. Ghorbel, C. Lopez, C. Michon, M. Ollivon, and P. Lesieur. 2009. Crystallization and polymorphism of triacylglycerols contribute to the rheological properties of processed cheese. J. Agric. Food Chem. 57:3195-3203.

Guinee, T. P., M. A. E. Auty, and M. A. Fenelon. 2000. The effect of fat content on the rheology, microstructure and heat-induced functional characteristics of Cheddar cheese. Int. Dairy J. 10:277288

Gwartney, E. A., E. A. Foegeding, and D. K. Larick. 2002. The texture of commercial full-fat and reduced-fat cheese. J. Food Sci. $67: 812-816$.

Hort, J., and G. Le Grys. 2001. Developments in the textural and rheological properties of UK Cheddar cheese during ripening. Int. Dairy J. 11:475-481.

Huttchings, J. B., and P. J. Lillford. 1988. The perception of food texture - The philosophy of the breakdown path. J. Texture Stud. 19:103-115.

Johnson, M. E., and C. M. Chen. 1995. Technology of manufacturing reduced-fat cheddar cheese. Pages 331-337 in Chemistry of Structure-Function Relationships in Cheese. E. L. Malin and M. H. Tunick, ed. Plenum Press, New York, NY.

Johnson, M. E., R. Kapoor, D. J. McMahon, D. R. McCoy, and R. G. Narsimmon. 2009. Reduction of sodium and fat levels in natural and processed cheese: Scientific and technological aspects. Comp. Rev. Food Sci. Food Safety 8:252-268.

Kalab, M., R. J. Lowrie, and D. Nichols. 1982. Detection of curd granule and milled curd junctions in Cheddar cheese. J. Dairy Sci. 65:1117-1121.

Lawrence, R. C., L. K. Creamer, and J. Gilles. 1987. Texture development during cheese ripening. J. Dairy Sci. 70:1748-1760.

Lopez, C., B. Camier, and J. Y. Gassi. 2007. Development of the milk fat microstructure during the manufacture and ripening of Emmental cheese observed by confocal laser scanning microscopy. Int. Dairy J. 17:235-247.
Lucey, J. A., M. E. Johnson, and D. S. Horne. 2003. Perspectives on the basis of the rheology and texture properties of cheese. J. Dairy Sci. 86:2725-2743

Mistry, V. 2001. Low fat cheese technology. Int. Dairy J. 11:413422.

Richardson, G. H. 1985. Standard Methods for the Examination of Dairy Products. 15th ed. Am. Publ. Health Assoc., Washington, DC.

Rogers, N. R., M. A. Drake, C. R. Daubert, D. J. McMahon, T. K. Bletsch, and E. A. Foegeding. 2009. The effect of aging on low-fat, reduced-fat, and full-fat Cheddar cheese texture. J. Dairy Sci 92:4756-4772.

Sala, G., T. van Vliet, M. A. Cohen Stuart, G. A. van Aken, and F. van de Velde. 2009. Deformation and fracture of emulsion-filled gels: Effect of oil content and deformation speed. Food Hydrocoll. 23:1381-1393.

Sandrou, D. K., and I. S. Arvanitoyannis. 2000. Low-fat/calorie foods: Current state and perspectives. Crit. Rev. Food Sci. Nutr. 40:427-447.

Ustunol, Z. K. Kawachi, and J. Steffe. 1995. Rheological properties of cheddar cheese as influenced by fat reduction and ripening time. J. Food Sci. 60:1208-1210.

van Vliet, T. 1988. Rheological properties of filled gels. Influence of filler matrix interaction. Colloid Polym. Sci. 266:518-524.

Visser, J. 1991. Factors affecting the rheological and fracture properties of hard and semi-hard cheese. Pages 49-61 in Rheological and Fracture Properties of Cheese. P. Walstra, ed. International Dairy Federation, Brussels, Belgium.

Vithanage, C. R., M. J. Grimson, and B. G. Smith. 2009. The effect of temperature on the rheology of butter, a spreadable blend and spreads. J. Texture Stud. 40:346-369.

Zhou, N., and S. J. Mulvaney. 1998. The effect of milk fat, the ration of casein to water, and temperature on the viscoelastic properties of rennet casein gels. J. Dairy Sci. 81:2561-2571. 